\title{
INTIMIDADE COM ESTRANHOS: UMA PERSPECTIVA KAXINAWÁ SOBRE CONFIANÇA E A CONSTRUÇÃO DE PESSOAS NA AMAZÔNIA*
}

\author{
Cecilia McCallum
}

\begin{abstract}
In memoriam
Francisco Lopes da Silva, cujo nome verdadeiro era Bixku, conhecido como "Pancho Kaxinawá" (1938-2006)
\end{abstract}

\section{Introdução}

A questão da intimidade tem sido central para os debates sobre socialidade e sobre a noção de pessoa na literatura sobre os povos das terras baixas da América do Sul. ${ }^{1}$ Ao longo das últimas décadas, os etnógrafos desenvolveram e chegaram a confrontar diferentes abordagens para a análise de corpos sociais e fisiológicos que diferem, marcadamente, em relação ao status heurístico da intimidade, retratada ou como parte constitutiva de sua configuração ou, alternativamente, como seu efeito. Estas abordagens conflitantes se apoiam em uma concepção comum de intimidade como resultado de interações prolongadas entre sujeitos humanos e conscientes, de tal forma que é associada com a mutualidade, a convivência e a socialidade vivida em comunidades estruturadas por laços de parentesco e afinidade. Para um tipo de análise, a intimidade é a engrenagem da construção da ordem social, enquanto para o outro, trata-se de um epifenômeno de processos estruturantes mais amplos que se alimentam de fontes externas àqueles domínios sociais em que sujeitos humanos interagem.

Eduardo Viveiros de Castro, figura-chave para o desenvolvimento desta última abordagem, cunhou a primeira como "a economia moral da intimidade" e batizou a sua própria como "a economia simbólica da alteridade" (Viveiros de Castro 1996a). ${ }^{2}$ Ele sugeriu que a primeira enfatiza a solidariedade conseguida moralmente e privilegia a discussão de relações sociais internas de grupos concebidos como mônadas sociais em detrimento de redes mais amplas de relações. Acusa seus criadores, nomeadamente 
Joanna Overing e alguns de seus ex-alunos, de uma visão irenista da socialidade amazônica, que a reduz "[a]o doméstico". ${ }^{3}$ A seu ver, ela contribuiu para o "estudo da filosofia social e a prática da socialidade cotidiana", mas, ele acrescenta em tom crítico,

[...] valoriza teoricamente a produção sobre a troca, as práticas de mutualidade sobre as estruturas de reciprocidade, e a ética da consanguinidade sobre a simbólica da afinidade. Apesar de sua rejeição à noção de sociedade como totalidade a priori dotada de uma racionalidade estrutural transcendente, este estilo, com sua visão essencialmente moral da socialidade, não deixa de ter analogias curiosas com a concepção fortesiana da Amity [...]. Por fim, a crítica cerrada à oposição público/doméstico [...] traduziu-se, não poucas vezes, em uma redução da sociedade ao nível doméstico (Viveiros de Castro 2002:335).

A abordagem alternativa da "economia simbólica da alteridade" é um desenvolvimento do estruturalismo lévi-straussiano que enfatiza o quadro sociocosmológico generativo mais amplo da vida social. Aqui, a produção da socialidade é vista como determinada em primeira instância pelas relações de alteridade, de tal modo que o externo engloba o interno, e o distante estabelece as condições de existência para a intimidade. Viveiros de Castro sintetiza:

Interessados nas inter-relações entre as sociologias e as cosmologias nativas, estes pesquisadores concentraram-se nos processos de troca simbólica (guerra e canibalismo, caça, xamanismo, rituais funerários) que, ao atravessarem fronteiras sociopolíticas, cosmológicas e ontológicas, desempenham um papel constitutivo na definição de identidades coletivas. Isso desembocou em uma crítica da noção de Sociedade como mônada fechada e autossubsistente [...]. Esta vertente explorou os significados múltiplos da categoria da afinidade nas culturas amazônicas (tema que aparece também em autores como Rivière ou Overing, mas de forma emicamente negativa) sugerindo seu valor de operador sociocosmológico central (Viveiros de Castro 1993) e buscando determinar a tensão entre identidade e alteridade que estaria na base dos regimes sociopolíticos amazônicos (Viveiros de Castro 2002:335-336).

Embora alguns, como Kelly Luciani (2003), tenham tratado estas diferentes abordagens como mero reflexo de diferenças nas ênfases teóricas, que podem ser interpretadas como complementares, outros, como Taylor (1996), distinguiram posições mutuamente excludentes e modelos analíticos muito diferentes. Em reação ao endurecimento da postura crítica dos adeptos do 
modelo da "economia simbólica", alguns entre os chamados "economistas morais" responderam com contracríticas. Para Overing e Passes, a abordagem estruturalista é insuflada de um viés modernista e racionalista que ignora os sujeitos vivos e conscientes e as atividades do cotidiano em detrimento de "estruturas grandiosas de mentalidade, cultura ou sociedade, inconscientes ou não" (2000:2). Os autores pedem foco na estética da vida social, em consonância com as preocupações dos povos indígenas, e insistem em que se dê atenção ao modo moralmente modelado da intimidade. Isto diz respeito a formas de se relacionar que incluem amor, cuidado, compaixão, e que levam ao "viver bem" - um conceito-chave na maior parte das filosofias sociais e políticas indígenas. Eles prosseguem, observando que muitos dos capítulos do livro ressaltam que

a ideia de uma socialidade do convívio jovial [...] captura, melhor do que a maioria das nossas noções de conexão social, a enorme valorização que os povos indígenas da Amazônia dão ao bom-humor, ao conforto afetivo e à mutualidade social em suas relações íntimas cotidianas e nas práticas de vida em comunidade (Overing \& Passes 2000:16).

A confiança de outros corresidentes é considerada um elemento-chave para a constituição deste dia a dia do "viver bem" entre íntimos (Overing 1999; Santos Granero 2007). Em relação à alteridade, Overing e Passes (2000) são cuidadosos ao ressaltar que o sucesso na criação da socialidade do convívio requer interação constante com aquilo que é "perigoso e diferente", antissocial e pernicioso. ${ }^{4}$ Eles negam, portanto, o que veem como a alegação de que ignoram as relações sociocosmológicas com estranhos, espíritos ou animais. Pelo contrário, observam que a incorporação de energias e poderes externos envolve a transformação de qualidades que são inerentemente antissociais em seu estado anterior à transformação, pertencendo a domínios em que a "socialidade sociável" não pode jamais ser vivida. Por meio do trabalho físico e ritual, as pessoas transformam os poderes externos em formas que podem ser benéficas para a vida cotidiana.

Ao longo dos 12 anos desde a publicação do livro de Overing e Passes, a distância entre as abordagens analíticas destes dois grupos frouxamente articulados tende a reaparecer sempre, apesar de muitos trabalhos etnográficos realizados nesse mesmo período desmentirem a pertinência ou o valor da suposta antinomia entre elas (Lagrou comunicação pessoal, 2012). Por exemplo, a etnografia de Lima (2005) ilustra com delicadeza que qualquer noção de que haja um vácuo radical entre as duas abordagens só pode ser ficcional. 
Mesmo assim, diversos autores preferem ignorar o trabalho daqueles que identificam como pertencentes ao campo oposto, e a distinção frequentemente se enraíza como "fato" no entendimento dos neófitos. A lucidez do esquema de Viveiros de Castro (1996a), publicado em português, em 2002, como capítulo de um livro muito usado nos cursos brasileiros de antropologia, sem dúvida contribuiu para este estado de coisas. Em suma, é evidente que, a despeito de contestações ocasionais publicadas com a ideia de que estamos lidando com modelos distintos e incompatíveis de socialidade, um reexame mais demorado ainda é necessário. O presente artigo constitui uma tentativa de reduzir a distância entre os proponentes de ambas as abordagens, ou mesmo de aboli-la. ${ }^{5}$ Para fazer isto, volto-me para uma teoria indígena da intimidade e seus efeitos para regimes locais de confiança e desconfiança, em uma exploração da etnografia dos Huni Kuin, povo amazônico mais conhecido na literatura como Kaxinawá. ${ }^{6}$

Os Huni Kuin vivem a maior parte de suas vidas em contato próximo com as mesmas pessoas e desenvolveram um modo sofisticado de organizar as relações entre si. Isto inclui um sistema de metades exogâmicas, a classificação de parentesco do tipo kariera e um sistema de nomeação de gerações alternadas compatível com ele. ${ }^{7}$ Eles dão preferência à endogamia e tentam convencer adolescentes a se casarem com seus primos cruzados. Para eles, a intimidade e a confiança estão conectadas. Para saber em que grau se pode confiar em uma pessoa, se ela tem o hábito de mentir, roubar ou se tornar violenta, deve-se ter vivido com essa pessoa ou ter acesso a alguém que o tenha feito. Como é de se esperar, é mais provável que uma pessoa com quem já se viveu proximamente seja mais confiável do que um estranho, mas isto não é sine qua non. Da mesma forma, alguém com quem se tem intimidade também pode ser uma fonte de perigo.

Há mais em jogo aqui do que a ontologia. A confiança não é o resultado de uma condição moral. A partir de sua perspectiva, aspectos-chave para a relação, como os sentimentos de confiança ou de se saber que se pode confiar em uma pessoa, entidade ou coisa, emergem do envolvimento com o mundo perceptível, que é, a um só tempo, material e imaterial - e nisto são semelhantes a outros amazonenses. Em um ensaio recente, Viveiros de Castro (2009:259), citando Gow (1991), menciona que, ao contrário do que acontece com a afinidade (que é experimentada como algo dado), "a consanguinidade amazônica é construída [...] mais ou menos seguindo as 
linhas do atual entendimento de parentesco: no sentido fenomenológico de ser o fruto de significativas práticas intersubjetivas". A discussão a seguir vai ao encontro desta observação, rumo a uma exploração da fenomenologia huni kuin e seu papel na imbricação instável de confiança e intimidade. Ela mostra que a confiança e a falta de confiança de outros, tanto íntimos quanto estranhos, partilham das mesmas origens, e que estas origens não são morais ou epistemológicas em um sentido abstrato. De fato, os Huni Kuin não são filósofos morais. Pelo contrário, confiança e desconfiança acontecem como eventos fenomenológicos e são pensados e tratados desta forma, isto é, associados a afetos e propriedades que são materialmente incorporados à pessoa ao longo do tempo e extrapolados em pensamento e ação intencionais. Como eventos epistemológicos, também são corporais. Explico estes pontos a seguir.

\section{Estranhos íntimos}

Enquanto os Nawa (estrangeiros, não humanos, estranhos) são invariavelmente indignos de confiança, com algumas exceções, os Huni Kuin se reconhecem como potencial e variavelmente inconstantes. ${ }^{8}$ Depois de dois anos vivendo com os Huni Kuin, percebi a mim mesma como uma Nawa transformada, parcialmente domesticada (McCallum 2010b). Quando otimista, sentia que poderia afirmar ter incorporado algo do modo de vida deles e, portanto, ser digna de sua confiança (uma condição que eu imaginava, com otimismo, que fosse recíproca). Então, foi com desgosto que vivenciei essa inconstância, em 1991, durante uma visita ao Acre, onde cerca de metade da população huni kuin reside. Pancho Lopes, o líder da aldeia Recreio, na Área Indígena Alto Purus ${ }_{1}^{9}$ onde eu vivera durante os anos 1980, me fez uma promessa e em seguida a renegou. Foi assim que eu descobri que não poderia confiar em uma pessoa que fora um informante-chave, importante para o sucesso de minha pesquisa de doutorado e que, por volta de oito anos antes do episódio relatado, deliberadamente me incluíra em seu círculo de confiança, como seu xanu, ou parente por afinidade, bem como me aceitara como corresidente de sua família.

Era 1991. Cheguei a Rio Branco, Acre, e então, como determina a legislação, me reportei à unidade local da Funai. ${ }^{10}$ Lá eu soube que uma nova regra obrigava potenciais pesquisadores visitantes de áreas indígenas a obterem consentimento prévio de um líder local. Pancho, por acaso, estava na cidade e prometeu apoio à viagem que eu planejava a Recreio. No entanto, quando fui ao escritório da Funai para obter a autorização final para 
a visita, um funcionário informou que ele tinha recusado. Com um sorriso (que eu senti) maldoso, o burocrata acrescentou: "Ele disse que dará o seu consentimento somente depois que você obtiver U\$100.000 em dinheiro para o desenvolvimento da aldeia". ${ }^{11}$ Mais tarde, queixei-me para o sobrinho de Pancho, Paulo Lopes, (meu epa - BS/genro) sobre as ações de seu tio, ao que ele deu de ombros e respondeu simplesmente, "Meu tio é assim — um dia ele é bom, outro mau".

Em que sentido huni kuin específico uma pessoa pode ser tanto boa quanto má, ou flutuar entre os dois? Ao longo deste artigo, demonstrarei que o comentário de Paulo pode ser remetido a uma teoria particular de agência dos Huni Kuin, que sustenta que capacidades particulares de agir permeiam o corpo (yura) em um sentido material (McCallum 2001). A agência posta em movimento numa ação correta é tanto uma condição quanto uma consequência do fazer de corpos "reais", isto é, corpos capazes de se envolverem em ação produtiva e reprodutiva. Ser propriamente humano — ou, colocado de outra forma, a pessoalidade - depende desse conhecimento e dessa capacidade incorporados.

Pancho me decepcionou, apesar de tudo o que havia feito no passado, no sentido de fazer de mim uma pessoa mais real, quer dizer, apesar de ter passado alguns anos transformando o meu yura nawa original numa entidade mais amena, mais compatível com os estilos huin kuin de socialidade. Era um trabalho feito de tal forma que eu seria capaz de contribuir positivamente para a constituição contínua da vida social em Recreio. Ao longo de meu trabalho de campo para o doutoramento e em várias visitas de pesquisa posteriores, travei muitas discussões com o líder, fui acompanhada por ele, viajei com ele, brinquei com ele como faz a xanu (prima cruzada) de um homem (McCallum 1997). Desde os primeiros momentos em que pisei nos barrancos do rio Purus, eu dependi de seu apoio. Vivi em sua casa por muitos meses.

Depois que me mudei para a minha própria habitação, a uns 20 metros de distância, continuei a fazer as refeições com ele e sua família. Em troca, ofereci o que podia: afora presentes, trabalhei com sua família quando ele esteve fora, ajudando a preparar a comida e a servi-la, colhendo com suas mulheres e filhas em suas roças, bem como, às vezes, executando outras tarefas que ele me pedia (tais como cuidar da loja cooperativa da aldeia, ou ensinar habilidades literárias a meninas adolescentes).$^{12}$ Ele via muitas vantagens em minha presença e muitas vezes procurou explorar meu poder percebido como nawa para benefício próprio ou dos habitantes da aldeia (McCallum 2010b). Compartilhávamos interesses - ele também buscava saber mais sobre os modos e a história huni kuin. Tudo isso me proveu de 
Figura 1 - Pancho lendo o Novo Testamento no Dia de Finados, Recreio, novembro de 1984 (๑ Cecilia McCallum)

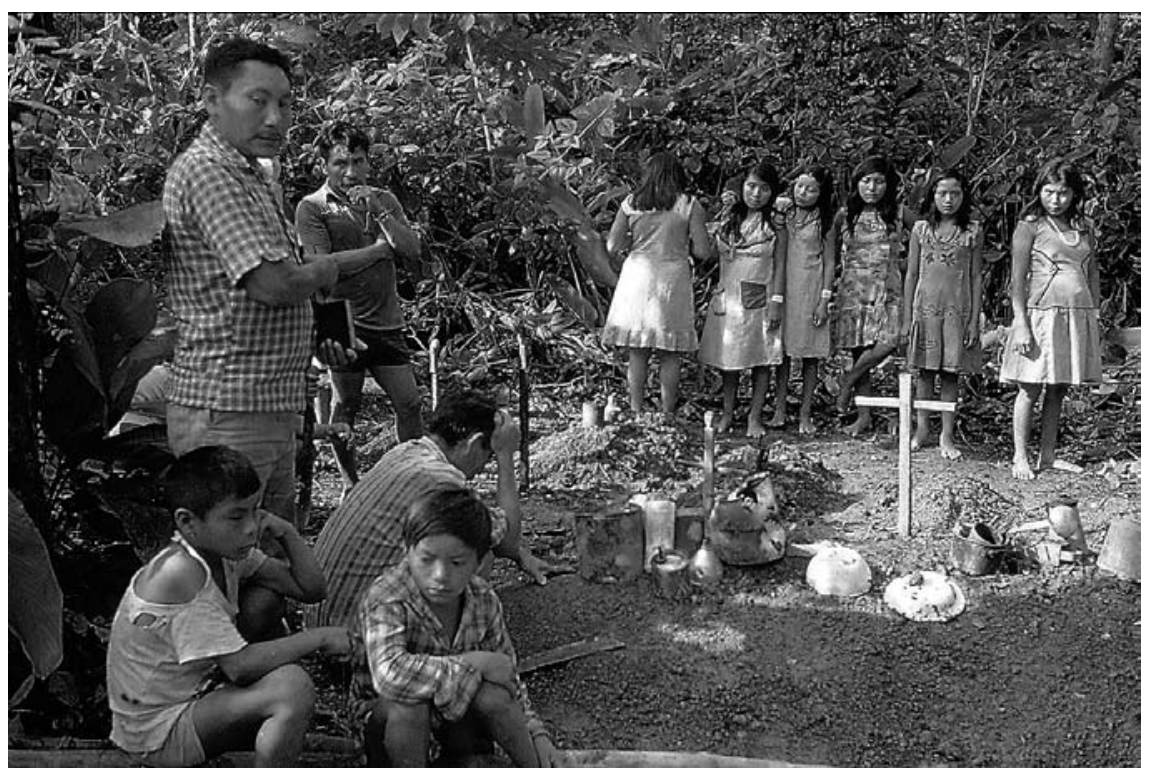

uma diminuta medida de intimidade compartilhada, lembrada e incorporada, tanto a partir da minha visão quanto da dele.

Na perspectiva huni kuin, em meu corpo, tal intimidade é registrada como xinan - um termo que pode ser traduzido como "pensamento", "memória" e também "confiança". ${ }^{13}$ Quanto ao nosso próprio relacionamento, não poderia dizer que eu xinan Pancho, no sentido de que eu realmente "confiava" nele, mas seria mais correto dizer que eu "sabia, reconhecia, lembrava, pensava" nele - e ainda o faço.

Quando Paulo disse que seu tio era às vezes mau, ele não estava brincando. De acordo com o relato do próprio Pancho, seu passado era marcado por disputas. Até o final dos anos 1970, ele morara em Balta, no rio Curanja, um afluente peruano do rio Purus. Ele me disse que sua migração rio abaixo para o lado brasileiro da fronteira fora motivada por uma disputa com um corresidente a quem ele acusara de ter agido como envenenador. Ele também alegou, em nossas primeiras semanas de relação, que ele mesmo assassinara diversas pessoas antes de sua conversão ao cristianismo evangélico.

Pancho levou sua conversão a sério. Na primeira vez em que morei em sua casa, ele gostava de sintonizar uma estação de rádio evangélica de madrugada para ouvir os sermões e organizava cultos regularmente, decla- 
rando-se um pastor da fé. Frequentemente estudava a tradução feita pelo Summer Institute of Linguistics do Novo Testamento que os missionários e seus colaboradores huni kuin peruanos fizeram. Como em outras partes da Amazônia, estas práticas não representam uma "conversão" no sentido da dispensa radical de uma tradição em favor da outra. ${ }^{14}$ Pancho tinha forte vínculo com o que ele percebia serem os autênticos modos huni kuin e se via como defensor de práticas kuin (verdadeiras): formas de educar as crianças, atribuir nomes e se casar; de comer e trabalhar junto; de curar e de vida ritual. Ele e outros "crentes" da aldeia expressavam sua fé como forma de incentivar o hive pe (viver correto) entre os Huni Kuin, não como rejeição total dos modos dos xenipabu (mais velhos). Não havia nenhuma evidência explícita de ruptura no campo religioso com corresidentes aparentados que se declaravam católicos ou (em poucos casos) "pagãos".

Distinções entre Huni Kuin (Pessoas Reais) e Nawa (não Huni Kuin) ${ }^{15}$ evidenciam-se de forma muito mais aguda na experiência cotidiana do que as diferenças religiosas internas. Nos anos 1980, os Huni Kuin enfrentaram um clima geral de extremo etnocentrismo em suas raras expedições para fora da Área Indígena Alto Purus. No entanto, havia alguns poucos apoiadores e amigos entre os Nawa. Eles podiam contar com as Irmãs Josefinas de Manuel Urbano, freiras católicas que ofereciam amparo e hospitalidade aos Huni Kuin e a outros visitantes indígenas (e também a eventuais antropólogos). Entretanto, uma noite, no final daquela década, quando Pancho e alguns outros Huni Kuin passaram a noite na casa simples de madeira que as irmãs normalmente ofereciam a esses hóspedes, um dos homens, dentre os Huni Kuin visitantes, foi assassinado. Pela manhã, seu corpo foi encontrado no jardim. Depois disso, as Irmãs Josefinas não mais quiseram oferecer sua hospitalidade a visitantes indígenas. ${ }^{16}$ Tendo perdido a confiança em Pancho, dali em diante adotaram uma postura mais cautelosa em relação a outros povos indígenas.

De uma perspectiva huni kuin, a história pessoal de Pancho deixara marcas em sua capacidade para (e nas atitudes perante) a ação social. Ele era um bom orador e um pensador lúcido, capaz de formular planos e projetos (xinan-) e persuadir pessoas a seguir a sua liderança. Ele tinha todas as qualidades clássicas dos líderes indígenas na Amazônia, como um dom para instigar esforços coletivos por meio da persuasão, ao invés de pela coerção. Foi assim que ele acabou conseguindo trazer com ele um grupo considerável de migrantes do Peru, no final dos anos $1970 .{ }^{17}$ Em 1984, numa expedição rio acima de que participei, ele inspirou mais algumas dezenas de parentes a navegar rio abaixo para se juntarem a ele em Recreio. Como resultado, a população huni kuin da AIAP aumentou de forma significativa, saltando de 250 pessoas - das quais 60 moravam em Recreio - em 1982, para 400, em 
Figura 2 - Líderes masculino e feminino durante uma reunião política: Pancho está sentado na mesa e sua esposa, Anisa, está de pé, dirigindo-se aos coaldeões - Recreio, rio Alto Purus, Brasil, 1984 (๑ Cecilia McCallum)

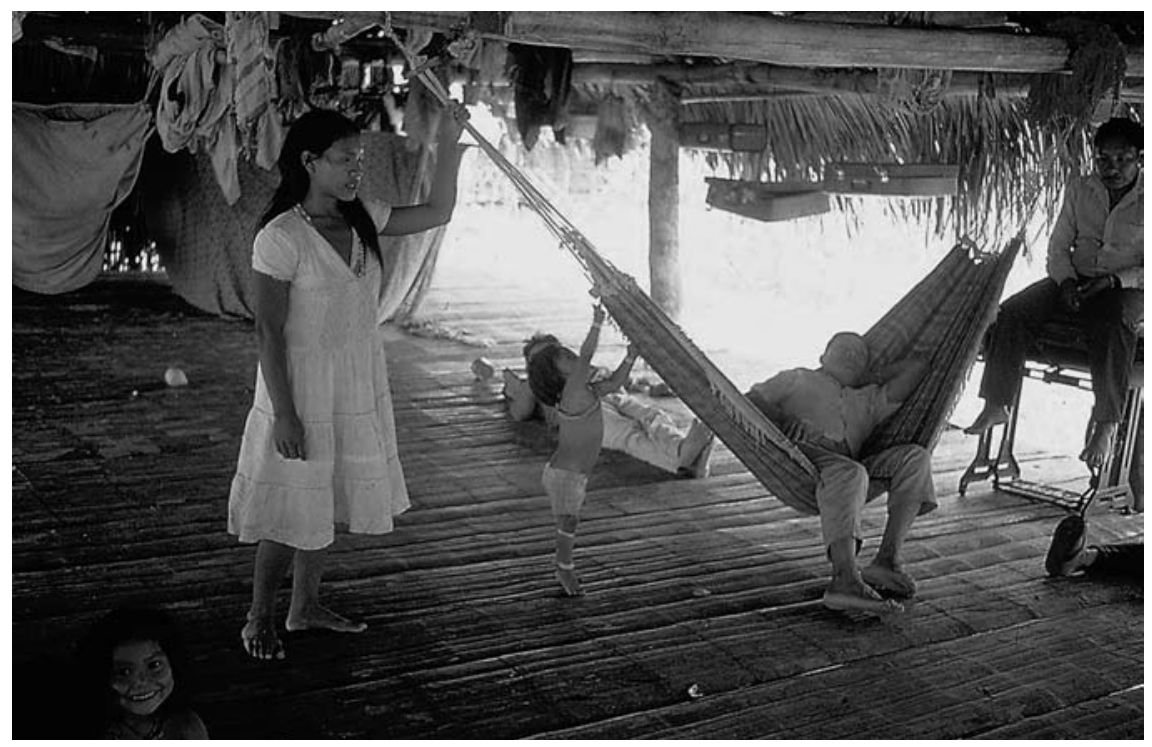

1985, das quais 137 em Recreio e 28 em Santa Vitória, novo assentamento que era satélite do primeiro (McCallum 1989:72, 79; Kaxinawá 2006).

Pancho também visitava destemidamente as cidades, envolvendo-se em política pró-direitos indígenas - regional e até mesmo nacional (certa vez chegou a visitar Brasília de ônibus). Assim, ele tentava garantir a demarcação legal do território indígena Purus e obter apoio econômico, educacional e de saúde que permitiria que a população se expandisse e melhor o assegurasse.

Assim como foi bem-sucedido em trazer pessoas para o povoado, ele também tinha habilidades na organização da vida cotidiana, fosse inspirando grupos de homens a trabalhar ou a caçar juntos ou iniciando ciclos rituais específicos. Ele obteve a cooperação de seu sogro, como líder de canto, e de sua esposa, que atuava como ainbu xanen ibu, líder feminina. Ela organizava as mulheres em tarefas coletivas e colaborava com Pancho, agindo como pivô em refeições coletivas que envolviam até 20 ou mais adultos - às vezes diariamente (McCallum 2001). Esta comensalidade estabelece o parentesco no sentido incorporado: estas são algumas das práticas que formam a base para a relação familiar coletiva, como nukun yura (nosso corpo) - ponto que explorarei mais detidamente adiante. 
Pancho era visto de forma ambivalente por seus parentes e afins. Ele podia ser dominador, exageradamente autoritário e (na visão de muitos corresidentes) às vezes encarnava as qualidades antissociais dos chefes Nawa (não Huni Kuin), os patrões que em certa época dominavam de forma autocrática os seringueiros endividados na maior parte do estado do Acre. ${ }^{18}$ Em minha última visita a Recreio, em 1990, a aldeia já se dividira em vários outros assentamentos, quase uma década depois de sua fundação. De fato, como muitos outros consanguíneos próximos e parentes por afinidade, que tinham tido uma longa história de corresidência com Pancho, o próprio Paulo não mais vivia com seu tio. À época em que a antropóloga Elsje Lagrou visitou o lugar pela última vez, em 1995, Pancho, cujas qualidades agora tinham sido superadas pelos atributos negativos, vivia "sozinho" com suas mulheres, filhos mais novos não casados, uma filha casada e seu genro. ${ }^{19}$ Seus filhos adultos não viviam com ele. Depois de anos ou décadas de intimidade, as condições para sua renovação tinham evaporado. Os aldeões saíram para fundar assentamentos menores e Recreio se dividiu.

Embora os parentes insatisfeitos ou insultados possam, em momentos de confronto, se distanciar de parentes com quem estão em conflito, Pancho não era mais nem menos Huni Kuin como resultado desta separação ou no momento em que agiu como catalisador para a formação da aldeia. A expressão "Huni Kuin" não é limitada a um grupo de pessoas que vivem coletivamente, nem simplesmente parte de um discurso normativo, mas remete a um processo histórico de construção corporal, que é a um só tempo singular e plural, como ficará claro a seguir. O que era tão especial em Pancho que fazia dele um líder tão bem-sucedido? E por que seus parentes acabaram perdendo a fé nele? Para responder a estas questões, retorno ao tópico do corpo e da incorporação do pensamento/confiança.

\section{A pessoa cumulativa}

Os Huni Kuin não vão tão longe quanto os Huaorani, que consideram as crianças como "hóspedes" ao nascer, antes que o tempo e a intimidade operem sua transformação em parentes (Rival 1998). Eles consideram que humanos não nascem prontos: são feitos, devagar e cumulativamente, pela modelagem progressiva e deliberada da forma e do conteúdo do corpo: ossos, dentes, carne e pele da criança. Isto acontece por sua imersão em campos sensoriais de som, visão, cheiro e toque cheios de significado. O conhecimento e a memória são integrados materialmente ao corpo por uma série de técnicas mundanas ou especiais, como parte de experiências ordinárias 
ou extraordinárias no mundo ao redor, de modo a formar Pessoas/Homens (Huni) Reais (Kuin) que são capazes de agir no mundo e interagir com outros de forma adequada, produtiva (real, verdadeira) (McCallum 1996b, 2001).

As capacidades assim estimuladas, que chamei alhures de "agência", são vistas como conhecimento e gênero incorporados, ou seja, feitos carne e osso. Um homem de verdade (huni kuin) e uma mulher de verdade (ainbu kuin) passaram por experiências que permitiram que incorporassem diferentes conjuntos de capacidades, de tal forma que, como pessoas vivas, são igualmente humanos, mas distintos em termos de gênero. Assim, embora gênero não seja essência, não seja "biologicamente determinado", se assenta materialmente no corpo como uma capacidade para a ação moral e social. É instilado de forma diferente em qualquer pessoa de verdade e, como outros resíduos de experiência, faz parte de sua (dele ou dela) individualidade existencial (McCallum 2001).

Esta é uma abordagem empírica da pessoalidade (cada corpo como o lugar de experiências passadas acumuladas) que deve ser entendida como condicionada por uma fenomenologia específica do ser - a pessoa cumulativa é tornada potente por um passado adequadamente direcionado. Cada corpo/ pessoa envolve, idealmente, um progresso estável — uma série de microadições à base original sem forma - uma acumulação que é tão epistemológica e imaterial quanto material. Todo o processo tem inflexões morais (a partir da perspectiva da análise antropológica) e é estruturado no âmbito da organização das relações de parentesco e afinidade. ${ }^{20}$ As pessoas resultantes deveriam ser capazes de se engajar plenamente na constituição da socialidade vivida por meio do envolvimento com outras dessas pessoas de verdade (e outros tipos de pessoas ou pessoas potenciais) em atividades produtivas e reprodutivas.

O processo envolve, portanto, uma pletora de interações com outras pessoas e entidades, e acontece em zonas ou ambientes temporais e espaciais distintos. Estes envolvem uma combinação de contatos externos (não humanos, outro corpo) e internos (nosso corpo), a partir dos quais a agência pode ser incorporada. Pela perspectiva da constituição de "pessoas" (huni) "verdadeiras" (kuin), as relações estratégicas envolvidas são aquelas com parentes próximos, íntimos (ou seja, relações corresidenciais, cotidianamente reforçadas). Dizer que alguém é um verdadeiro homem ou uma verdadeira mulher é dizer que sua história de se tornar uma pessoa envolveu trocas próximas com verdadeiros parentes "consanguíneos" e por afinidade. São pessoas que tanto são feitas por quem é próximo a elas quanto são capazes de fazer outros verdadeiros parentes.

Não há garantia de que o produto desse processo seja a pessoa cumulativa ideal, uma pessoa de verdade. O progresso só é garantido pela constante 
atenção ao detalhe, repetições diárias de palavras e outros atos, a interminável constituição do próprio corpo e daqueles dos outros. A ingestão de comida, a sensação dos remédios dentro e sobre o corpo, assim como a pintura da pele, o uso de roupas, redes e outros objetos, a absorção material de homilias, a externalização de habilidades em atividades produtivas geradas em interações físicas, sexuais e reprodutivas, tudo isso contribui para esta pessoalidade cumulativa. Pessoas de verdade são corpos pronominais são o meu/o nosso yura.

Tais corpos são constituídos por relações sociais e organizados no âmbito de e entre metades e seções de homônimos em gerações alternadas. Assim como os pais, os avós homônimos são figuras-chave para fazer com que crianças cresçam. Portanto, não é raro que a avó materna de uma menina, que é de sua seção de homônimos ou cujo nome pertence à mesma seção de homônimos que o de sua neta, cuide dela diariamente. Meninos desenvolvem laços próximos com o pai de sua mãe MF, com frequência corresidentes e assumindo a responsabilidade da "fabricação" dos filhos de suas filhas. O nome do MF (txai) pertence à mesma seção daqueles dos primos cruzados (também denominados de txai) do menino. Mais tarde, parceiros sexuais, idealmente primos cruzados bilaterais, continuam o processo de fazer corpos de verdade por meio da corresidência e do compartilhamento de substâncias sexuais e comida.

Esse processo não se dá sem sobressaltos. Há obstáculos, problemas, desvios, partidas de diversos tipos. Doença, morte, loucura, emoções fortes e o distanciamento em relação aos que foram íntimos geram transformações no corpo, suas capacidades e seu conteúdo. Pode se tornar outro, não mais uma verdadeira pessoa - talvez um Nawa, um animal, ou um yuxin (espírito). ${ }^{21}$ O sofrimento excessivo ou o desejo pode ser mortal. O mero conhecimento de técnicas socialmente destrutivas é capaz de abalar as bases deste progresso. Uma pessoa que aprende a envenenar ou enfeitiçar a outra pode não mais atuar como um verdadeiro parente, por exemplo, porque a capacidade de matar permanece latente.

Não há, desta forma, caminhos simples para a pessoalidade adequada, incorporada. A alteridade é central para o processo de se tornar uma pessoa. O crescimento resulta da colocação em contato com o que é diferente, e muitas vezes perigoso, por meio de uma diversidade de contatos relacionais: como predador ou presa, como interlocutor ou espectador, amigo ou parceiro. Uma vez que tais encontros afetam o corpo materialmente, alterando seu próprio conteúdo de forma benéfica (ou o contrário), não se pode equacionar a pessoalidade cumulativa com uma condição de identidade acabada. Cada pessoa é diferente, e assim, não há Huni Kuin iguais em essência, apenas 
corpos compostos, cumulativos que solidificam a história de sua própria feitura, momentaneamente, ao longo do percurso de uma vida, antes da dissolução trazida pelo processo da morte (McCallum 1996a, 1999).

O processo de construção de uma pessoa de verdade - masculina ou feminina - é conceituado como teleológico — como o trabalho em direção a um fim ideal - mas o produto desse processo não é reificado, já que corpos - por conseguinte, pessoas - são eminentemente transformáveis. ${ }^{22}$ Assim, na "antropologia reversa" dos Huni Kuin, um Nawa pode começar a ser transformado numa espécie de aproximação do verdadeiro homem ou mulher (McCallum 2010b). ${ }^{23}$ Em etiologias amazônicas indígenas, de maneira geral, a doença é passível de ser entendida como a transformação de pessoas em animais ou espíritos (Vilaça 2011). Os Huni Kuin consideram os loucos como yuxin, não pessoas de verdade.

Quando nasce um bebê huni kuin, portanto, o seu status em cada momento de sua passagem pela vida não tem condição de ser previsto ou garantido. Em tese, ele pode se transformar em qualquer coisa ou pessoa. Pancho é um caso em questão. Quando criança, foi vítima das transformações corpóreas que ocorrem quando jovens meninos são adotados ou abduzidos por Nawa. Ele foi levado por um comerciante peruano mestiço em visita à aldeia de Balta, e foi parcialmente criado por uma família mestiça de construtores de canoas que viviam no rio Purus, em localidade distante vários dias descendo-se o rio desde a nascente do Curanja. A história de parte de sua infância lembra um conto de Dickens. Ele rememorava maus-tratos, castigos (inclusive físicos, algo abominado pelos Huni Kuin), trabalho sem remuneração e condições de vida empobrecidas. Como forma de compensação, ele aprendeu o espanhol regional e obteve uma compreensão geral dos costumes mestiços que mais tarde lhe serviriam bem. ${ }^{24}$ Seus insights astutos dos Nawa locais eram, em parte, baseados nessas experiências de infância desagradáveis.

De uma perspectiva huni kuin, o fazer específico do corpo de Pancho sua pessoa acumulada - derivava, em certa medida, do período passado na casa mestiça. Naquele ambiente hostil, ele incorporou a agência nawa, bem como a huni kuin. Em sua vida posterior, o comportamento dominador, raivoso ou avarento foi entendido como se emanando da própria inflexão corporal: era o seu corpo individual que tinha a capacidade e/ou a tendência de realizar ações antissociais, bem como praticar e instigar ação social própria. Pode-se dizer que seu corpo incorporava sua própria "forma de ser", como o "kwere" dos Wari' (Vilaça 2011). Quando voltado para o bom uso - para o benefício de pessoas de verdade - não importava, tudo era para o bem. Mas seu passado particular dava ainda mais instabilidade ao seu corpo de pessoa de verdade. 
Isto me traz de volta a questão da confiança. Em que sentido Pancho era xinanika (digno de confiança, atencioso) para seu próprio povo? Como deve ter ficado claro, nenhum corpo individual é inteiramente confiável, qualquer que seja sua história pessoal. Esta é uma consequência da instabilidade corporal do pensamento (xinan). A confiança como pensamento tem uma qualidade líquida. Em uma síntese recente sobre o assunto, Belaunde (2005) mostra que, para muitos povos amazônicos, a corrente sanguínea é o veículo ativo da consciência. É como os pensamentos fluem pelo corpo. A lógica geral detalhada por Belaunde parece ser aplicável ao caso dos Huni Kuin. Ao aceitá-la, pode-se inferir que xinan (os pensamentos) são transportados pelas veias e artérias do corpo em forma líquida, e de fato os sinais apontam para isto. Embora eu nunca tenha ouvido alguém dizer precisamente tal coisa, os Huni Kuin afirmaram que o pensamento permeia o corpo inteiro, como disseram a Kensinger nos anos 1950 e 1960. Muitos informantes insistiam que pensar acontece yura medan "dentro do corpo", achando graça da noção de que esteja confinado em apenas um órgão, como o cérebro (Kensinger 1995:242-243).

Um corpo saudável e ativo tem xinan paxa - "pensamentos frescos, verdes" - sendo paxa um termo usado para descrever milho novo quando ainda está macio e doce (xeki paxa). O sangue é uma substância poderosa e perigosa, imbuída de capacidade transformacional. A hemofagia é um pensamento repulsivo para os Huni Kuin, e eles cozinham bem a carne para evitá-la. O sangue nunca deve ser ingerido em forma líquida e crua, exceto na ocasião de rituais muito restritos (Lagrou 2007). ${ }^{25}$ Se minha inferência está correta, ingerir sangue seria consumir os pensamentos de outros corpos. Como consequência, a ingestão ritual do sangue de outros corpos é a ingestão dos seus pensamentos. Embora não se diga explicitamente que é um yuxin (espírito), o sangue certamente é a substância xamanística mais poderosa, como insiste Lagrou. Os pensamentos irrigam os diferentes órgãos, como a genitália, o coração, o fígado e a pele, onde emoções, conhecimento e capacidades específicos estão concentrados e a partir deles pensamentos particulares se formam e fluem para fora (Kensinger 1995; McCallum 1996b, 1998b; Lagrou 2007). O fígado segura os pensamentos de forma especialmente concentrada, e é lá que as emoções se condensam.

Uma pessoa que é doce (bata) pensa bem, se lembra dos outros, age com generosidade. Um bom líder é um bata ibu - um pai ou patrão doce. Ele e sua mulher, a líder feminina, fazem os corpos de corresidentes se juntarem e compartilharem do jeito humano correto e desejado. Seus pensamentos conscientes, então, ao se transformarem a partir dessa substância-pensamento (sangue) incorporada e se tornarem palavras e ações, são 
necessários para a criação de confiança. A memória do cuidado, do afeto, da sociabilidade assume a forma de pensamento líquido. Esses pensamentos incorporados são uma condição necessária para que se faça a intimidade social, e a qualidade do pensamento (doce ou amargo) produz diferentes resultados: a socialidade constituída ou destruída.

Pensamentos-emoção podem tanto pesar numa pessoa quanto elevá-la a uma sensação aérea. A tristeza e o lamento engrossam o sangue, de modo que a pessoa se torna letárgica e pesada. A felicidade é sentida como uma leveza do ser, descrita como xinan chankan - pensamentos leves. A vida, no entanto, não pode ser baseada em mera leveza, e um líder ou pai precisa de algum peso em seu pensamento. Precisa de seriedade para dar propósito à ação, direção ao pensamento ou, poder-se-ia dizer, dar-lhe intencionalidade. É preciso uma perspectiva clara e consciente sobre os outros para motivar suas ações. Neste sentido, ser xinanika (digno de confiança) é exercer uma força centrípeta sobre um campo de intimidade, caracterizado pela memória substantiva porém instável (porque líquida).

Pancho foi capaz de fazer isso ao longo dos muitos anos em que atuou mais frequentemente como um bata ibu do que como um patrão nawa. A força exercida por ele, em conjunção com suas mulheres e (posteriormente) genro e filhas, constituiu o que pode ser descrito como uma pessoa expandida, um corpo (yura) coletivo dentro do qual o fluxo de substâncias benéficas intencionais assume a forma de comida e fluidos sexuais, ao invés de sangue. ${ }^{26}$ A comunidade, como yura vivo, é construída na imagem do corpo preenchido de pensamento/sangue. É uma arena social em que a confiança é desejada, mas não garantida. Formado na base da colaboração conjugal, o corpo coletivo deriva de suas atividades formadoras de corpo, como crianças derivam metonimicamente de seus pais. Neste sentido, os dois líderes, masculino e feminino, são literalmente os ibu (pais, donos) da aldeia, o que se captura na expressão traduzida como líder, xanen ibu. O pensamento empírico que resulta na noção de um corpo cumulativo, portanto, não deveria ser entendido como limitado aos confins de corpos biológicos discretos. Ele inclui um círculo de intimidade dentro de e entre certos corpos. Embora um corpo seja sempre intencional, seus pensamentos dirigidos para outros, ele pode envolver ou ao menos penetrá-los. Se esses pensamentos são doces e nascem de uma fonte sólida de memória afetiva positiva, o pensador também deve ser digno de confiança.

Esta confiabilidade é uma forma de pensamento afetivo que gera tipos de ação específicos. É inerentemente instável, uma condição vinculada à sua qualidade geralmente líquida; como força agenciadora que circula no sangue, concentra-se em certos órgãos e dá energia e sentido às ações de uma pessoa em relação a outras. 
Esta formulação pode ser relacionada ao entendimento do corpo estabelecido no "perspectivismo amazônico" (Viveiros de Castro 1998; Lima 1996). A expressão se refere à sistematização da filosofia ou ontologia indígena, como se exprime na exegese e na prática da Amazônia e das terras baixas da América do Sul. Como se encontra em trabalhos anteriores de autores que escrevem sobre a "economia simbólica da alteridade", o foco recai sobre as relações com o exterior, nas quais muitos seres se veem como humanos. Estes seres - vistos por humanos vivos como animais, espíritos ou plantas veem a si mesmos como sujeitos humanos. Autores do perspectivismo enfatizam que cada tipo diferente de corpo está no centro daquela forma específica de ser ou ontologia.

O corpo é a base da perspectiva, sua origem. Aquelas espécies que se veem como humanos também entendem possuir cultura humana. Ao invés de um cosmo composto de uma natureza única e múltiplas culturas, pessoas indígenas pensam em algo composto por uma única cultura e múltiplas naturezas (Viveiros de Castro 1998). Em termos formais, há apenas um tipo de sujeito, que é humano. A forma indígena de expressar essa identidade formal é associar uma "alma" (ou almas) a estes humanos autoidentificados. O corpo, que é a base da distinção, envolve as almas como uma peça de roupa ou traje de mergulho passível de ser removido ou mudado. A alma pode ser transferida ou transformada em outro corpo de animal, planta ou espírito.

Deve-se observar que a aplicabilidade universal desta formulação tem aceitação ampla, mas não total, entre etnógrafos de povos indígenas do continente. Muitos, entretanto, (mas não todos) aceitam a presença de ontologias perspectivistas. ${ }^{27} \mathrm{O}$ pensamento e a prática huni kuin também podem ser considerados perspectivistas, como sugere a discussão acima. Eles, assim, identificam uma variedade de plantas e animais (não todos) como huni ou gente e direcionam muito de sua energia à manutenção de fronteiras claras entre eles mesmos e essas outras "pessoas". ${ }^{28}$ No entanto, grande parte da discussão do perspectivismo se preocupa em explorar as relações com seres de fora (caça, xamanismo), em consonância com as preocupações anteriores com a alteridade de Viveiros de Castro e outros. Mas o perspectivismo também deveria prover um suporte útil para explorar relações internas envolvendo os diferentes corpos de parentes e outros corresidentes. Não precisa se restringir ao foco de "processos de troca simbólica (guerra e canibalismo, caça, xamanismo, rituais funerários) que [...] atravessa $(\mathrm{m})$ fronteiras sociopolíticas, cosmológicas e ontológicas" (Viveiros de Castro 1998:190).

Por meio da sistematização do perspectivismo indígena, diz-se que a abordagem da "economia simbólica da alteridade" deu uma "virada ontológica" (Costa \& Fausto 2010). Abundantes estudos etnográficos da 
"sociocosmologia" indígena, grande parte em português, têm trazido as "ontologias" indígenas para o centro do debate. As consequências práticas da formulação antropológica do perspectivismo amazônico são extremamente diversas, como a profusão de estudos demonstra. Além do Brasil, o trabalho em ontologias semelhantes na Sibéria e alhures traz à cena comparações regionais (Willerslev 2007). De fato, o trabalho sobre o perspectivismo tem sido recebido como inovação teórica enraizada em modos indígenas de pensar (Moore \& Sanders 2006).

Em relação ao cenário das terras baixas da América do Sul, poucas vozes críticas têm se levantado, dentre as quais aquela de Terry Turner (2009), que define o perspectivismo como o último suspiro de um "estruturalismo tardio" e falho. Adotando uma postura marxista, o autor se opõe à visão de que ameríndios consideram o sujeito como formalmente idêntico em todas as espécies, ou que a diferença se localiza em corpos. Para os propositores do perspectivismo, ele escreve, "os corpos visíveis das diferentes espécies [...] não têm nada a ver com as suas identidades subjetivas como humanos" (Turner 2009:26). Ele critica a observação de Viveiros de Castro de que o espírito ou alma é a forma interna do animal, "uma intencionalidade ou subjetividade formalmente idêntica à consciência humana" (Viveiros de Castro 2004:465 apud Turner 2009), como consequência problemática da ideia de multinaturalismo. Se é este o caso, decorre que a roupagem externa - o corpo - é desprovido tanto de consciência quanto de humanidade. O autor prossegue ridicularizando a noção de que os corpos sejam "invólucros" ou "roupagens" para a alma ou espírito do animal.

No contexto da presente discussão do corpo como nexo de intimidade e veículo de confiança, esta ideia requer atenção. Para Viveiros de Castro, o "corpo-traje de mergulho" é o locus de "afetos" — ou seja, de capacidades e disposições, formas de ser que constituem uma espécie de habitus. Este habitus é diferente para cada animal ou ser. A aparência não é medida de identidade: apenas se pode saber que um corpo é diferente de outro pela maneira como se comporta, não em função de como é na aparência. Assim, uma pessoa que come carne crua não é humana, mas, talvez, um jaguar; uma criança que range os dentes enquanto dorme está se tornando um pecari, e assim por diante. Esses corpos em processo de devir jaguar ou pecari mudam a forma de ser que eles "vestem", por assim dizer, de acordo com as mudanças de perspectiva, isto é, os estilos de comportamento de seus corpos se alteram ao se movem para a perspectiva diferente. A transformação do corpo é concomitante com a mudança de ponto de vista. Pela ótica dos que estão observando, embora se possa "saber" como identificar outros corpos como aparentemente humanos, apenas os comportamentos 
(o efeito do habitus) proveem algum tipo de garantia de que suas perspectivas correspondem.

Turner centra sua crítica desta discussão do corpo como postulado pelo perspectivismo amazônico numa dicotomia entre natureza e cultura. Ele repreende Eduardo Viveiros de Castro (a quem se refere como EVC) do seguinte modo:

Com efeito, a reformulação do conceito de habitus se torna a base indispensável para a reimportação da oposição estruturalista de natureza e cultura como moldura para o conceito de EVC de identidade animal, de uma forma que deixa o componente cultural (espiritual, humano) intacto e isolado do aspecto corporal natural e bestial da criatura (Turner 2009:27).

Turner sugere em seguida que o autor vê corpo e alma, forma externa afetiva "natural" e conteúdo interno "cognitivo", como dissociados.

Parece-me que esta acusação é infundada. Esta leitura da formulação do perspectivismo é amplamente desmentida em grande parte da etnografia contida em estudos feitos sob a bandeira perspectivista. Não há espaço aqui para uma dicotomia Natureza-Cultura (já criticada em trabalho anterior de Viveiros de Castro $^{29}$ ). A questão em debate concerne à natureza do chamado corpo "invólucro" (ou "traje de mergulho"). Para os Huni Kuin, o yura, com todos os seus afetos, não deve ser visto senão como densamente imbuído de espírito (consciência humana), ponto este que também pode ser disposto da forma inversa. Enquanto vivem, os yuxins (espíritos, incluindo os que envolvem consciência, pensamento, memória e confiança) de uma pessoa são densamente imbuídos em seu corpo ou yura.

Recentemente, trabalhos sobre o perspectivismo foram complementados com desenvolvimentos na teoria que emerge não apenas da etnografia das terras baixas da América do Sul, mas também de um diálogo mais amplo com trabalhos em outras regiões etnográficas (notadamente a Melanésia). Isto alterou o vocabulário que os americanistas usam para discutir cosmologia, socialidade e pessoalidade. Críticas, conceitos, formulações teóricas enriquecem seu armamento conceitual para a reinterpretação etnográfica. ${ }^{30}$ Assim, ecoando uma tendência mais ampla na antropologia mundial, estão reelaborando formulações etnograficamente derivadas, como a "dividualidade", a partir de uma profunda releitura da etnografia amazônica. ${ }^{31}$

Estes entendimentos específicos de dividualidade são moldados, em seu conjunto, em um suporte estruturalista. Lévi-Strauss continua a inspirar trabalhos inovadores, notadamente por meio do desenvolvimento de sua noção de "dualismo dinâmico", elaborada de forma mais completa 
em um de seus ensaios mais recentes, Histoire de lynx (1991). ${ }^{32}$ De acordo com Viveiros de Castro (2001), este, "o lado escuro da lua estruturalista", é para Lévi-Strauss o "princípio de movimento do processo cosmológico ameríndio [...] um dualismo em desequilíbrio perpétuo ou dinâmico" (:30). O dualismo em questão é tomado como um "princípio lógico que implica uma ordenação do mundo em pares estáveis que são sucessivamente diferenciados" (Vilaça 2011:249). Em sua extensão mais ampla, o cosmos é concebido como uma fonte infinita de alteridade, em contraposição ao seu oposto lógico, a identidade. Para que pessoas de verdade possam existir, é necessária a sua distinção em relação a inimigos e outros estranhos. Mais do que isso, é preciso que haja semelhantes, extraídos a partir dos outros. Cito a descrição sucinta de Vilaça:

Como mostrou Viveiros de Castro (2001) em um trabalho em que explora a noção de dualismo lévistraussiana, relacionando-a explicitamente com o modelo melanésio de pessoa, essa dicotomia se reproduz em todos os níveis do sistema, do coletivo ao individual, de acordo com um modelo fractal (2001:19; ver Kelly 2005). Assim, os próprios conterrâneos se diferenciam em afins e consanguíneos, os últimos em irmãos de mesmo sexo ou cruzados (ou entre mais novos e mais velhos), até que se chega ao indivíduo que, como mostra Viveiros de Castro, não é um "individual" (2001:25), mas um "dividual" (idem:33), constituído de corpo e alma, sendo o primeiro o seu lado conterrâneo ou consanguíneo, e o segundo, o seu polo inimigo ou afim. No processo de produção do parentesco analisado por Viveiros de Castro (2001) nesse artigo, o polo "afim" é sistematicamente eclipsado - e jamais eliminado - nos diferentes níveis desse modelo fractal. É a persistência da afinidade que responde pelo caráter instável do dualismo, por produzir novos pares, em um movimento contínuo (e infinito) de extração da afinidade (Vilaça 2011:249).

Assim, “[...] na Amazônia, a afinidade é o que aparece como a dimensão dada de uma matriz cósmica relacional, enquanto a consanguinidade inserese no âmbito da ação e da intenção humana" (Viveiros de Castro 2001:19). O modelo de Wagner das dialéticas de convenção e invenção elucida melhor os modos indígenas de constituir parentesco a partir da diferença. O processo criativo posto em movimento por pares assimétricos retratados como "estruturas estruturantes" ou (de modo mutável) "processos estruturantes" (Viveiros de Castro 2001:41) dá forma e direção à prática. A dinâmica generativa é a da obviação: uma série de progressões superimpostas desde estados não demarcados até estados demarcados, do virtual ao atual, da afinidade à consanguinidade, do corpo animal ao corpo humano, e assim por diante, 
resulta na ontologia indígena conhecida como "perspectivismo amazônico". Este é, portanto, um modelo que também daria conta de teorias e práticas indígenas em relação à criação de elementos e relações familiares para os habitantes do mundo perceptível.

A nova síntese vai além dos relatos estruturalistas, abrindo espaço para uma reconexão entre áreas de interesse de antropólogos que tinham sido separadas. Ela sugere que uma análise proveitosa procuraria relacionar "socialidade virtual" (a fonte convencional de parentesco, a esfera da alteridade) à "socialidade vivida" (o domínio fenomenológico, a esfera inventada da identidade).

Contudo, o fantasma de um substantivismo falido assombra a apreensão do autor de estudos de "socialidade vivida". O dualismo dinâmico é usado explicitamente para invalidar o que Viveiros de Castro (2001) chama de "visões fenomenais" ou moldadas pelo construcionismo social de relações de parentesco no contexto amazônico (uma referência ao estilo de análise dos adeptos da dita "economia moral da intimidade"). A primeira instância do processo analítico do parentesco, ele escreve, não deveria ser tomada simplesmente como relações reais entre pessoas vivas. Se este fosse o caso, a socialidade seria levada a parar onde a sociabilidade termina (Viveiros de Castro 2001:22). Pelo contrário, ao revelar a lógica conceitual por trás do pensamento e da prática indígena, demonstra-se que o parentesco é delineado a partir de um cosmos habitado por diversos seres com quem as pessoas de verdade precisam lidar. Neste sentido, a socialidade não pode ser reduzida ao mundo do parentesco vivido, já que o último é concebido como um resultado inacabado das sucessivas diferenciações de pares de opostos.

Viveiros de Castro continua a trabalhar no programa apresentado nesta síntese teórica mais recente, como também têm feito muitos outros. No entanto, é cedo para ver se o fim da polarização "economia moral da intimidade"/"economia simbólica da predação", que seu ensaio parece prometer, pode realmente ser concretizado. Até o presente, alguns dos tópicos-chave explorados pelos analistas classificados outrora como "economistas morais", como o gênero, a produção e a sociabilidade, permanecem marginalizados ou mesmo sub-representados por aqueles que trabalham no âmbito dos parâmetros deste último modelo, como foram pelo próprio Lévi-Strauss. ${ }^{33}$ De fato, embora The Gender of the Gift, de Strathern (1988), seja uma importante fonte de ideias frescas, o próprio tema de gênero foi escalado como essencialmente desimportante para a tarefa de entender a socialidade nas terras baixas. Muitos leitores brasileiros enfatizam a preocupação de Strathern com a forma e interpretam sua análise como essencialmente estruturalista. ${ }^{34}$ 
Alguns se inspiram em Descola (2001), que apresentou a visão bizarra de que o gênero é de relativa pouca importância para a compreensão da socialidade amazônica em um livro dedicado à discussão comparativa de gênero na Melanésia e na Amazônia. Recentemente, Vilaça (2011) observou que o gênero desempenha "um papel muito mais central na compreensão antropológica da socialidade na Melanésia" (:244) do que na Amazônia, onde - ela prossegue - as relações-chave para a constituição da socialidade são aquelas entre humanos e não humanos. Ela argumenta que a distinção de gênero é coberta pela distinção humano/não humano. No entanto, o perigo aqui é que o modelo do(a) analista o(a) conduz a um território muito além dos modos indígenas de entendimento e prática. Diria mais: para os próprios povos indígenas, todo processo de produção e reprodução — ou a própria vida — está centrado no corpo composto e "generizado" — ou seja, imbuído de gênero. Se o gênero é relegado desta forma, torna-se apartado da visão analítica (embora não da etnográfica).

Então há perigos nesse entusiasmo estruturalista pelo divíduo na Amazônia. ${ }^{35}$ Poder-se-ia perguntar: a transposição da noção de divíduo, ao mesmo tempo em que ressalta de forma proveitosa a natureza incorporada, instável do parentesco, não levaria a uma perda de visão da natureza histórica e intencional (em sentido fenomenológico) da pessoalidade huni kuin? O perigo é que o leitor desatento pode ser levado a ignorar o que as pessoas indígenas dizem a respeito dos efeitos da passagem do tempo biográfico e da sedimentação da memória e do afeto. Poder-se-ia perguntar, ainda: ao dar pouca atenção, no nível do modelo, à etnografia da pessoalidade cumulativa (a pessoa humana viva ou que já viveu, provida de gênero, imbuída de memória e habilidades adquiridas e conhecimento) em prol de uma ênfase dada ao divíduo fractal e sem gênero, é possível perceber o processo dinâmico no qual a socialidade vivida é constituída?

O processo depende de gênero como conhecimento incorporado ou "agência". Não é apenas como ancoragem para uma perspectiva humana que os Huni Kuin veem corpos, mas, quando em repouso, como ação humana potencial e, quando em movimento, sua realização ou negação. O que fazem ou não fazem é o que os torna mais ou menos aparentados, mais ou menos humanos. É este aspecto do corpo que as diversas formulações estruturalistas delineadas neste artigo deixaram de iluminar. Esta falta deriva em grande medida de leituras pouco generosas ou errôneas de etnógrafos que foram identificados com a "economia moral da abordagem da intimidade", quando se diz que o seu trabalho endossa uma visão substantivista da pessoalidade e, portanto, uma análise essencializadora ou mesmo reificadora. 
A atribuição de uma visão substantivista da pessoalidade tem sérias implicações. Na antropologia social, ela atuou como a base para a ideia de que as relações sociais são mais bem entendidas como interações entre sujeitos moral e fisicamente distintos. Se este fosse o caso, isto implicaria que a sociológica indígena baseia-se na visão de que a sociedade é o resultado de relações entre indivíduos concebidos como separados biologicamente (mesmo parecendo uma evocação estranha de um funcionalismo estrutural obsoleto) com a diferença de que estes corpos separados são "construídos culturalmente" de uma forma huni kuin única. Este não é o propósito por trás da noção da pessoa cumulativa. Pelo contrário, a expressão tem a intenção de chamar a atenção para a centralidade de uma fenomenologia especificamente indígena na visão dos Huni Kuin sobre a socialidade.

Argumentei que a noção de pessoa cumulativa não se refere a uma totalidade acabada, o produto final de uma série de adições materiais e infinitas para um sujeito unitário e progressivamente unificado. A noção de pessoa fractal é uma forma elegante de capturar as forças centrípetas em ação - ou, de outro modo, o movimento recursivo e repetitivo de fora para dentro, a incorporação histórica ou biográfica do potencial para a ação. O que está ausente neste modelo é o corpo em movimento - no gasto de energia e conhecimento assim obtido.

Muitas discussões etnográficas têm reafirmado o enquadramento de Seeger et al. (1987) da relação entre corporalidade e forma e processo social na Amazônia indígena. Elas notaram que a sociológica indígena está acima de toda uma fisio-lógica, expressando-se em idioma corporal, sobre e através de corpos. Se o pensamento social se centra de fato no corpo, ele trata o corpo não como fixo ou dado, mas como algo em movimento, fluido e transformável. Recentemente, isto recebeu ênfase considerável (Vilaça 2002, 2005, 2011). O que recebeu menos atenção, seja em publicações em inglês ou em português, foram o conhecimento, as disposições e as capacidades para a ação inerentes ao corpo já moldado (mesmo que seja transformável): ou seja, um conhecimento que é tanto ativo como efetivo. ${ }^{36} \mathrm{O}$ pensamento social se preocupa com as ações do corpo e suas capacidades para a ação, com sua habilidade para se engajar de forma bem-sucedida na produção, bem como na reprodução (Belaunde 2005). Pessoas de Verdade, com corpos cumulativos, são capazes de entrar em ação apropriada, socialmente produtiva, isto é, são entendidos como imbuídos de uma agência especificamente humana. A socialidade viva pode ou não ser o resultado da conjunção estruturada (estruturante) de tais agências (dentre as quais, agências masculinas e femininas são as variáveis centrais e complementares). Então, a lógica, que é ao mesmo tempo fisiológica e social, depende de uma fenomenologia 
indígena específica, que se manifesta nas práticas que capacitam pessoas vivas para a ação social em um sentido ontogenético.

A ação requer poder e conhecimento materialmente incorporados, e também memória afetiva - a lembrança do cuidado passado - para lhe dar coerência e direção. ${ }^{37}$ As origens destas capacidades e emoções são diversas, mas podem ser distinguidas, de acordo com a forma de sua aquisição, em dois tipos: as obtidas enquanto o corpo está em estado consciente, e as adquiridas em estados alterados de consciência, por exemplo, ao dormir, em função de doenças graves, ou ao tomar substâncias alucinógenas (Kensinger 1995; McCallum 1996b, 1998b). Se a criação da socialidade viva depende das ações humanas - e, portanto, destes tipos específicos de agências contidas em carne e osso, então isto claramente deriva da história do seu fazer, isto é, a sociologia indígena não depende de uma teoria do corpo como télos em um sentido ontológico, mas se pauta numa fenomenologia histórica do yura. É este quadro mais amplo de sentido que quero evocar quando me refiro ao corpo cumulativo.

A fenomenologia indígena engloba corpos (de todos os tipos - humanos, animais, espíritos) e "coisas", bem como ações e reações, forças e resistências. É uma fenomenologia que se sustenta conceitualmente não na imutabilidade da matéria, mas em sua instabilidade: a transformabilidade de corpos em corpos ou coisas, de matéria nessas formas de não matéria que podem ser sentidas ou conhecidas por meio dos sentidos (vento, ou sons, ou visões, ou cheiros). Assim, é uma fenomenologia arraigada no fluxo temporal — passado e presente, visto na história, ou previsto na futurologia um fluxo que é uma condição necessária para a existência humana. A maior parte das descrições citadas do "divíduo" ou "pessoa partível" coloca forte ênfase na forma vista como parte da estruturação de relações por meio de processos infinitamente recursivos de dualismo dinâmico. Mas perde-se aqui o peso atribuído pelos povos indígenas à pessoa cumulativa que, como vimos, é composta de memória e experiência. Isto se expressa como a qualidade da matéria que faz um corpo — ossos, dentes e a própria carne substância essa que pode apodrecer e se transformar. Conhecimento e emoção se acumulam na substância e a permeiam, dando-lhe real gravidade, ancorando-a em um tempo-espaço específico (o da realidade consciente) e em um campo relacional peculiar (de trocas com outros corpos como esses). Quando dormindo ou em um estado alterado de consciência, a âncora é temporariamente suspensa, e o yuxin pode se distanciar do corpo (como faz, de forma definitiva, na morte). Estas oscilações na consciência correspondem a sucessivas mudanças de perspectiva - a dos vivos para a dos mortos - e constituem o fluxo temporal do tempo diário. 
O tempo biográfico expressa o infinito potencial para a individualidade dos corpos em questão. Ao passar pela vida, a alma do corpo (yura yuxin) de uma pessoa adquire mais e mais peso e poder. Pancho era o produto de uma série de eventos específicos, de seu movimento pessoal através do espaço e do tempo, que lhe deu capacidades e qualidades únicas, como a qualquer outro huni kuin. Na forma de pensamento (xinan), infundiram-se em seu corpo, fluindo em seu sangue, fazendo dele um sujeito intencional, alguém que podia dirigir sua visão a outros, lembrar-se deles, reconhecê-lo como digno de confiança (xinanika). Afinal, o fato de que muitas pessoas escolheram fazê-lo diz respeito à poderosa capacidade da intimidade de fazer e desfazer socialidade. Tendo vivido com ele, sendo ou tornando-se seu yura (no sentido de parente), elas compartilharam corpo com ele. Mas se aceitarmos que a intimidade baseada na confiança é uma pré-condição para a socialidade vivida, a intimidade não pode ser conceituada meramente como o produto de uma interação próxima e prolongada entre pessoas conscientes, já que a própria consciência deriva igualmente da intimidade com estranhos.

Um último ponto deve ser defendido. Este artigo começou por declarar que tem o objetivo de contribuir para a dissolução da suposta oposição entre duas abordagens da socialidade e da organização social entre povos indígenas na Amazônia, uma das quais associada ao foco na intimidade e na moralidade, e a outra, na alteridade e no simbolismo. Argumentei, entretanto, que esta é uma falsa dicotomização, e que deveríamos ver a socialidade pela perspectiva da fenomenologia indígena (e não pela euroamericana), que foi claramente descrita na literatura sobre os Huni Kuin. Isto trata o yura como composto, contendo tanto a semelhança quanto a diferença; como único, engajado em processos micro-históricos; como fractal, incorporando o parentesco em um sentido dinâmico e formal; como dimensionado, pertencendo aos processos integrados da socialidade vivida no interior de corpos singulares e também nos corpos plurais dos parentes.

O quadro analítico que surge da perspectiva "simétrica" proposta neste ensaio é consoante com insights e argumentos-chave de ambas as abordagens. Ao focalizar a geração histórica do parentesco, a noção de que os antropólogos devem escolher entre uma ênfase maior na predação ou na produção, na intimidade ou na exterioridade, na consanguinidade ou na afinidade perde o sentido. Esta conclusão, uma vez aceita, anula os termos nos quais a própria oposição é expressa.

Recebido em 28 de agosto de 2012

Aprovado em 26 de fevereiro de 2013

Tradução de Fernanda Guimarães 
Cecilia McCallum é professora adjunta no Departamento de Antropologia e Etnologia da Universidade Federal da Bahia. E-mail:<Cecilia.McCallum@ uol.com.br>

\section{Notas}

* Um enorme agradecimento a Margit Ystanes e Vigdis Broche-Due, organizadoras do workshop "The Entangled Tensions of Intimacy, Trust and the Social", para o qual o presente artigo foi originalmente escrito. O evento foi organizado pelo Grupo de Pesquisa de Políticas da Pobreza (Poverty Politics Research Group) do Departamento de Antropologia Social da Universidade de Bergen, na Noruega, como parte do subprojeto "Os Efeitos da Marginalização e da Violência na Saúde Psicossocial" ("The Effects of Marginalization and Violence on Psychosocial Health"), financiado pelo Conselho de Pesquisa da Noruega, e aconteceu em Bergen de 18 a 20 de maio de 2012. Resultou no livro ainda inédito intitulado Trust, Intimacy and the Social. Agradeço também aos organizadores e participantes do seminário de Antropologia da Universidade de Manchester, onde também apresentei o artigo em maio de 2012. Luisa Elvira Belaunde e Els Lagrou fizeram comentários valiosos a uma versão anterior. Sou grata a elas e aos pareceristas anônimos deste periódico. O Conselho de Pesquisa Econômica e Social (ESRC) da Grã-Bretanha, a Fundação Leverhulme e a Fundação Nuffield financiaram a pesquisa com os Huni Kuin entre 1983 e 1992. Toda a responsabilidade pelo resultado final é exclusivamente minha.

${ }^{1}$ A expressão "terras baixas da América do Sul" refere-se a uma região cultural que se concentra em sociedades amazônicas, mas inclui povos tão distantes geograficamente quanto os que vivem da América Central à Terra do Fogo.

${ }^{2}$ Uma versão em português foi publicada em Viveiros de Castro (2002).

${ }^{3}$ Estão, entre os muitos antigos alunos de Overing, além de mim, Peter Gow, Luisa Elvira Belaunde e Fernando Santos Granero.

${ }^{4}$ Overing (1981), em um artigo muito citado, demonstrou que a contínua manutenção de comunidades endogâmicas relativamente fechadas depende da alteridade.

${ }^{5}$ Santos Granero (2007) defende uma visão semelhante em relação à natureza infeliz e desnecessária da percepção de uma divisão entre estas duas abordagens analíticas, as quais, sugere ele, Viveiros de Castro (1998) não apresentou como excludentes, nem vê como "modelos inflexíveis de socialidade amazônica nativa". 
${ }^{6}$ Nos últimos anos, líderes huni kuin pediram que sua autodenominação fosse usada ao invés de "Kaxinawá".

${ }^{7}$ Kensinger (1995); McCallum (2001).

${ }^{8}$ A questão da inconstância é talvez a mais antiga da etnologia dos povos indígenas do Brasil. Em seu capítulo sobre "a inconstância da alma selvagem", Viveiros de Castro cita um sermão publicado em 1657 pelo jesuíta Padre Antonio Vieira, que lamentava a maleabilidade excessiva dos Tupinambás convertidos (Viveiros de Castro 2002).

${ }^{9}$ A Área Indígena Alto Purus, que os Huni Kuin, falantes de língua pano, compartilham com os Kulina (que falam arawã), é a maior do estado do Acre.

${ }^{10}$ Acrônimo para Fundação Nacional do Índio.

${ }^{11}$ Dois fatores contribuem para esta reivindicação. Um foi uma contingência muito dinheiro desenvolvimentista estava sendo distribuído no Acre, como parte do financiamento do Banco Interamericano de Desenvolvimento para a pavimentação da rodovia principal que conectava o estado ao restante do Brasil. Em um acordo estabelecido com o fim de pacificar ambientalistas e outros movimentos sociais que se opunham a esta atividade, o desembolso de recursos para a estrada incluía o financiamento de projetos voltados para a "proteção" dos povos indígenas e do meio ambiente. O segundo fator foram as minhas próprias (malogradas) tentativas, ao longo dos dois anos anteriores, de obter fundos para um projeto apoiando os Huni Kuin do Alto Purus, que eu havia enviado a diversas ONGs, como por exemplo à Rainforest Foundation.

${ }^{12}$ Ver McCallum 1989, 2001, 2010a, 2010b.

${ }^{13}$ Montag (1981:405) considera "confiar" uma das traduções possíveis para o verbo xinan-.

${ }^{14}$ Ver Vilaça (2011) sobre a conversão na Amazônia; e Vilaça (2006) para a conversão Wari'.

${ }^{15}$ Nawa também é traduzido como "não índio/s, inimigo/s, estranho/s, espírito/s inimigo/s", dependendo do contexto.

${ }^{16}$ Não é minha intenção inferir que Pancho tenha sido necessariamente o perpetrador do assassinato, mas ele foi o principal suspeito. As missionárias ficaram profundamente perturbadas com estes acontecimentos. Elas me contaram os contornos gerais da história como forma de explicar sua decisão de não mais oferecer a casa para visitantes indígenas em Manoel Urbano. Os acontecimentos daquela noite permanecem misteriosos e, até onde sei, nenhuma acusação formal foi registrada.

${ }^{17}$ Ver entrevista com Pancho (Kaxinawá 2006) e o seu obituário por Valle de Aquino e Iglesias (2006). 
${ }^{18}$ Ver McCallum (1990) sobre diferentes estilos pessoais das lideranças kaxinawá (huni kuin) e as relações com patrões não indígenas.

${ }^{19}$ Esses processos de fissuras (e fusões) em assentamentos são constituídos no âmbito dos processos de socialidade vivida, tratados neste artigo através da perspectiva da fenomenologia huni kuin. A partir de uma perspectiva sociológica e histórica, eles podem ser vistos como o contexto do qual emergem a confiança e a desconfiança. O tema merece discussão mais extensa, mas isso está para além do alcance deste artigo.

${ }^{20} \mathrm{O}$ sistema onomástico, que incorpora oito grupos de nomeação, nos quais os nomes são transmitidos entre gerações alternadas, se integra a um sistema de metades exogâmicas. Um número limitado de nomes divide-se entre as metades Inu e Dua. Eles são concedidos de acordo com um princípio de "transmissão paralela". Assim, uma menina herda o seu nome de uma mulher na categoria de avó materna, e um menino, de um homem na categoria de avô paterno. Práticas de casamento, fundamentais para a reprodução do sistema, são compatíveis com a terminologia de parentesco kariera. Os filhos de casamentos entre primos cruzados bilaterais herdam nomes das categorias corretas e os Kaxinawá estimulam ativamente esses casamentos “corretos" (Kensinger 1984; D'Ans 1990; McCallum 2001:21-27, 1989).

${ }^{21}$ Para uma discussão anterior sobre o corpo huni kuin, ver McCallum 1996b. Muitos estudos etnográficos conduzidos alhures nas terras baixas da América do Sul descrevem entendimentos semelhantes da maleabilidade e da transformabilidade do corpo. Ver, por exemplo, Gow 1989; Kelly Luciani 2003; Taylor 2000; e Vilaça (2005, 2011) para uma apreciação recente.

${ }^{22}$ Este ponto é bem estabelecido na literatura. Contudo, a consideração da pessoa cumulativa foi negligenciada, já que é frequentemente confundida com a ideia de que a noção indica uma (falsa) preocupação com a autoidentidade e uma ordem moral fixa.

${ }^{23}$ Refiro-me à discussão proposta por Wagner na abertura de $A$ invenção da cultura (1975). Se a ideia da antropologia reversa é tomada para pressupor que o outro é um ser humano a priori, ela então não seria aplicável estritamente ao caso dos Huni Kuin. Os Nawa são potencialmente pessoas/humanos em um gradiente de humanidade para a alteridade, em que a pessoalidade cumulativa é a pré-condição para a futura geração de socialidade vivida. No entanto, os Nawa nunca atingem plenamente a condição acumulada, material, de um ser humano de verdade.

${ }^{24}$ Ken Kensinger, que fez pesquisa extensa e pioneira com os Huni Kuin (Kaxinawá) peruanos, gentilmente me enviou uma fotografia de Pancho, aos 11 anos, tirada por ele quando passou pela casa dessa família mestiça. Ele também confirmou detalhes da história de Pancho sobre sua vida entre eles.

${ }^{25}$ Meninos consomem o coração, o fígado e o sangue da jiboia para adquirir habilidades de caça; meninas engolem seus olhos para ver desenhos e aprender a trançá-los. Dentre outras qualidades assim adquiridas, está o xinan da cobra (Lagrou 2007:352). 
${ }^{26}$ Para a noção de "pessoa expandida", ver Cesarino (2010) para os Marubo, e Lima (2005) para os Yudya. Ver também Lagrou (2007).

${ }^{27}$ Turner (2009) nega que os Kayapó sejam perspectivistas. Ver também Kohn (2009) e Ramos (2012) para discussão crítica e maiores referências.

${ }^{28}$ Lagrou (2007) provê uma análise brilhante do perspectivismo huni kuin, dentre outras coisas.

${ }^{29}$ Ver, por exemplo, Viveiros de Castro (1986).

${ }^{30}$ Como explicam Costa e Fausto (2010), a influência de filósofos franceses, tais como Deleuze e Guattari, para esta tendência foi importante. Trabalhos-chave referenciados incluem Strathern (1988), Wagner (1975), Gell (1998), por exemplo.

${ }^{31}$ Ver, por exemplo, Hugh-Jones (2001); Kelly Luciani (2003); Vilaça (2011); Lima (2005).

${ }^{32}$ Ver Viveiros de Castro $(2001,2002)$. Outros estudos que se utilizam da noção de "dualismo dinâmico" para explorar as ontologias indígenas nas terras baixas da América do Sul incluem Lagrou (2007, 1998), Lima (2005), Vilaça (2011).

${ }^{33}$ Costa e Fausto (2010) notam que gênero é uma área subexplorada. Ver a entrevista de Lagrou e Belaunde (2011) com Viveiros de Castro para suas opiniões sobre os equívocos, as omissões e os exageros de Lévi-Strauss em relação ao gênero.

${ }^{34}$ Nisto, reconhecem os comentários de Gell (1998) sobre o assunto. Tenho em mente, por exemplo, Viveiros de Castro (2001, 2002); Vilaça (2011) e Lima (2005). Ver também Lagrou e Belaunde (2011), que citam Viveiros de Castro sobre Strathern, autora que ele explicitamente considera ter elaborado a primeira teoria propriamente estruturalista das relações de gênero.

${ }^{35}$ Há outros temas que permanecem abertos, por exemplo, as consequências político-econômicas deste uso da noção de divíduo para os regimes amazônicos de socialidade. Refiro-me aqui a análises comparativas que isolaram o trabalho como o valor econômico-chave nas terras baixas da América do Sul, onde regimes de serviço de noiva prevalecem, ao invés daqueles de preço de noiva típicos da Melanésia, em que o casamento "abre" caminhos para a troca de dons. Embora os termos deste debate sejam agora de certa forma datados, os temas de poder, produção, reprodução e troca como centrais para a constituição da relacionalidade merecem maior atenção à luz dos debates recentes discutidos aqui.

${ }^{36}$ Refiro-me a este aspecto do corpo como "agência", um termo que se popularizou nos anos 1990 e recentemente foi submetido à crítica. Por exemplo, Sahlins (2011) sugere que "agência" implica a imposição da noção de um indivíduo único, com limites bem delimitados, como fonte de ação. É evidente que esta não é a virada de sentido que eu aplicaria ao uso do termo agência no contexto huni kuin, 
já que agência é uma condição fractal, uma relacionalidade incorporada, antes de mais nada.

${ }^{37}$ Aqui vale lembrar que Gow $(1989,1991)$ afirma que a memória afetiva é central para a criação dos laços de parentesco.

\section{Referências bibliográficas}

BELAUNDE, Luisa Elvira. 2005. El recuerdo de luna: género, sangre y memoria entre los pueblos amazónicos. Lima: FEFCS. 2001. Viviendo bien: género y fertilidad entre los Airo-Pai de la Amazonia peruana. Lima: CAAAP / BCRP.

CESARINO, Pedro. 2010. “Donos e duplos: relações de conhecimento, propriedade e autoria entre os Marubo". Revista de Antropologia, 53(1):147-197.

COSTA, Luiz \& FAUSTO, Carlos. 2010. “The return of the animists: recent studies of amazonian ontologies". Religion and Society: Advances in Research, 1:89-109.

D'ANS, André-Marcel. 1990. "La parenté et le nom: sémantique des désignations interpersonnelles cashinahua". L'Ethnographie, 107:55-87.

DESCOLA, Philippe. 2001. "The genres of gender: local models and global paradigms in the comparison of Amazonia and Melanesia". In: T. Gregor \& D. Tuzin (eds.), Gender in Amazonia and Melanesia: an exploration of the comparative method. Berkeley: University of California Press. pp. 91-114.

GELL, Alfred. 1998. Art and agency. An anthropological theory. Oxford: Clarendon Press.

GOW, Peter G. 1989. "The perverse child: desire in a native Amazonian subsistence economy". Man (N.S.), 24:299-314.

. 1991. Of mixed blood: kinship and history in Peruvian Amazonia. Oxford: Clarendon.

HUGH-JONES, Stephen. 2001. "The gender of some Amazonian gifts: an experiment with an experiment". In: T. Gregor \& D. Tuzin (eds.), Gender in Amazonia and Melanesia: an exploration of the comparative method. Berkeley: University of California Press. pp 245-79.

KAXINAWÁ, Pancho. 2006. "Nossa luta nunca acaba, continua sempre". In: Papo de Índio, Rio Branco, Acre, domingo, 26 e segunda-feira, 27 de março de 2006. Disponível em Página 20 online: http://pagina20.uol.com. br/26032006/papo_de_indio.htm. Acesso em 30/05/2013.

KELLY LUCIANI, José Antonio. 2003. Relations within the health system among the Yanomami in the Upper Orinoco, Venezuela. PhD. Thesis, University of Cambridge. - 2005. "Notas para uma teoria do 'virar branco'". Mana. Estudos de Antropologia Social, 11(1):201-234.

KENSINGER, Kenneth. 1984. "An emic model of Cashinahua marriage". In: K. Kensinger (org.), Marriage 
practices in Lowland South America. Urbana, IL: University of Illinois Press. pp. 221-251.

- 1995. How real people ought to live: the Cashinahua of Eastern Peru. Prospect Heights: Waveland Press.

KOHN, Eduardo. 2009. "A conversation with Philippe Descola". Tipití: Journal of the Society for the Anthropology of Lowland South America, 07:135-150.

LAGROU, Elsje \& BELAUNDE, Luisa Elvira. 2011. "Do mito grego ao mito ameríndio: uma entrevista sobre Lévi-Strauss com Eduardo Viveiros de Castro". Sociologia e Antropologia, 1(2):09-33.

LAGROU, Elsje M. 1998. Cashinahua cosmovision: a perspectival approach to identity and alterity. PhD Thesis, University of St. Andrews. Disponível em: http://research-repository.st-andrews.ac.uk/handle/10023/281. 2007. A fluidez da forma: arte, alteridade e ação em uma sociedade amazônica (Kaxinawá, Acre). Rio de Janeiro: Topbooks.

LÉVI-STRAUSS, Claude. 1991. Histoire de lynx. Paris: Plon.

LIMA, Tânia Stolze. 1996. "Os dois e seu múltiplo: reflexões sobre o perspectivismo em uma cosmologia tupi". Mana. Estudos de Antropologia Social, 2(2):21-47.

- 2005. Um peixe olhou para mim: o povo Yudjá e a perspectiva. São Paulo: Editora UNESP/ Instituto Socioambiental/ NUTI.

MCCALLUM, Cecília. 1989. Gender, personhood and social organization among the Cashinahua of Western Amazonia. Tese de doutorado, London School of Economics, University of London. . 1990. "Language, kinship and politics in Amazonia". Journal of the Royal Anthropological Institute, 25: 412-433. 1996a. "Morte e pessoa kaxinauá". Mana. Estudos de Antropologia Social, 2:49-84.

. 1996b. "The body that knows: from Cashinahua epistemology to a medical anthropology of Lowland South America". Medical Anthropology Quarterly, 10:347-372.

. 1997. "Comendo com Txai, comendo como Txai: a sexualização de relações étnicas na Amazônia contemporânea". Revista de Antropologia, 40:109-147. . 1998a. "Alteridade e sociabilidade kaxinauá: perspectivas de uma antropologia da vida diária". Revista Brasileira de Ciências Sociais, 13(38):127-136. 1998b. "O corpo que sabe: da epistemologia kaxinauá para uma antropologia médica das Terras Baixas SulAmericanas". In: Paulo Cesar Alves \& Miriam Rabelo (orgs.), Antropologia da saúde: traçando identidade e explorando fronteiras. Rio de Janeiro: Fiocruz/ Relume Dumará. pp. 215-245.

_. 1999. "Consuming pity: the production of death among the Cashinahua". Cultural Anthropology, 14(4):443-471. -2001. Gender and sociality in Amazonia: how real people are made. Oxford: Berg.

2010a. "Escrito no corpo: gênero, educação e socialidade na Amazônia numa perspectiva Kaxinawá". Revista da FAEEBA: Educação e Contemporaneidade, 19(33):87-104. Disponível em: http://www.ppgeduc.com/revistadafaeeba/anteriores/numero33.

. 2010b. "Becoming a real woman: alterity and the embodiment of Cashinahua gendered identity". Tipití: Journal of the Society for the Anthropology of Lowland South America, 7:43-66.

MONTAG, Susan. 1981. Diccionario cashinahua. 2 vols. Yarinacochá: Instituto Linguistico de Verano. 
MOORE, Henrietta \& SANDERS, Todd. 2006. Anthropology in theory: issues in epistemology. Oxford: Blackwell.

OVERING Kaplan, Joanna. 1981. "Review article: 'Amazonian anthropology'". Journal of Latin American Studies, 13(1):151-165.

. 1999. "Elogio do cotidiano: a confiança e a arte da vida social em uma comunidade amazônica". Mana. Estudos de Antropologia Social, 5(1): 81-107.

OVERING, J. \& PASSES, A. (orgs.). 2000. "Introduction". In: The anthropology of love and anger: the aesthetics of conviviality in native Amazonia. London: Routledge. pp. 01-30.

RAMOS, Alcida Rita. 2012. "The politics of perspectivism". Annual Review of Anthropology, 41:481-494.

RIVAL, Laura. 1998. "Androgenous parents and guest children: the Huaorani couvade". JRAI, 4(4):619-642.

SAHLINS, Marshall. 2011. "What is kinship? Part two". Journal of the Royal Anthropological Institute, N.S. (17):227-242.

SANTOS-GRANERO, Fernando. 2007. "Of fear and friendship: Amazonian sociality beyond kinship and affinity". Journal of the Royal Anthropological Institute, 13(1):01-18.

SEEGER, Anthony; DAMATTA, Roberto \& VIVEIROS DE CASTRO, Eduardo. 1987 [1979]. "A construção da pessoa nas sociedades indígenas brasileiras". In: João Pacheco de Oliveira (org.), Sociedades indígenas \& indigenismo no Brasil. Rio de Janeiro: UFRJ/ Editora Marca Zero. pp. 11-29.

STRATHERN, Marilyn. 1988. The gender of the gift: problems with women and problems with society in Melanesia. Berkeley: University of California Press.

TAYLOR, A.C. 1996. "The soul's body and its states: an Amazonian perspecti- ve on the nature of being human". Journal of the Royal Anthropological Institute, N.S. (2):201-15.

- 2000. "Le sexe de la proie. Représentations Jivaro du lien de parenté". L'Homme, 154/155:309-334.

TURNER, Terence. 2009. "The crisis of late structuralism. Perspectivism and animism: rethinking culture, nature, spirit, and bodiliness". Tipití: Journal of the Society for the Anthropology of Lowland South America, 7:03-42.

VILAÇA, Aparecida. 2002. "Making kin out of others in Amazonia". Journal of the Royal Anthropological Institute, N.S.(8):347-365. . 2005. "Chronically unstable bodies: reflections on Amazonian corporalities". Journal of the Royal Anthropological Institute, N.S(11):445-464. - 2006. Quem somos nós: os War'i encontram os Brancos. Rio de Janeiro: Editora UFRJ.

2011. "Dividuality in Amazonia: god, the devil, and the constitution of personhood in Wari' Christianity". Journal of the Royal Anthropological Institute, 17(2):243-262.

VIVEIROS DE CASTRO, Eduardo B. 1986. Arawete: os deuses canibais. Rio de Janeiro: Jorge Zahar.

. 1993. "Alguns aspectos da afinidade no dravidianato amazônico". In: E. B. Viveiros de Castro \& M. M. Carneiro da Cunha (eds.), Amazônia: etnologia e história indígena. São Paulo: Núcleo Hist. Indígena/ USP. pp. 150-210.

_. 1996a. "Images of nature and society in Amazonian ethnology". Annual Review of Anthropology, 25:179-200.

- 1996b. "Os pronomes cosmológicos e o perspectivismo ameríndio". Mana. Estudos de Antropologia Social, 2(2): 115-144. 
- 1998. "Cosmological deixis and Amerindian perspectivism". Journal of the Royal Anthropological Institute, N.S.(4):469-488.

_.2001. "GUT Feelings about Amazonia: potential affinity and the construction of sociality". In: L. Rival \& N. L. Whitehead (eds.), Beyond the visible and the material. Oxford: OUP. pp. 19-43.

- 2002. A inconstância da alma selvagem. Rio de Janeiro: Cosac Naify.

_. 2004. "Perspectival anthropology and the method of controlled equivocation". Tipití, 2(1):03-22.

_ 2009. "The gift and the given: three nano-essays on kinship and magic". In: S. C. Bamford \& J. Leach (orgs.), Kinship and beyond: the genealogical model reconsidered. New York, Oxford: Berghahn Books. pp. 237-268.

VALLE DE AQUINO, Txai Terri \& IGLESIAS, Marcelo Piedrafita. 2006. "Uma homenagem ao velho Pancho Kaxinawá, da Terra Indígena Alto Purus". In: Papo de Índio, Rio Branco, Acre, domingo, 26, e segunda-feira, 27/03/2006. Disponível na Página 20 online: http://pagina20. uol.com.br/26032006/papo_de_indio. htm. Acesso em 30/05/2013.

WAGNER, Roy. 1975. The invention of culture. Chicago: The University of Chicago Press.

WILLERSLEV, Rane. 2007. Soul hunters: hunting, animism, and personhood among the Siberian Yukaghirs. Berkeley: University of California Press. 
Resumo

Este artigo reexamina distintas abordagens que tratam da constituição da socialidade em contextos indígenas amazônicos, as quais diferem no que diz respeito ao valor heurístico atribuído à "confiança" e à "intimidade", à luz da etnografia dos Huni Kuin (Kaxinawá) sobre o corpo, a noção de pessoa, a confiança e o pensamento. Para os Huni Kuin, o pensar e o confiar são processos incorporados e constitutivos da socialidade vivida. Partindo de uma apreciação crítica dos usos de esquemas analíticos que emergem das discussões sobre o "perspectivismo amazônico" e a "fractalidade", desse modo colocando em relevo ontologias indígenas em ação, o artigo mostra que é necessário ir além de uma ênfase ontológica para considerar sua interface com a epistemologia e a fenomenologia indígenas. Concluo que o entendimento perspectivista huni kuin da dinâmica entre socialidade virtual e socialidade vivida em um universo multinatural se apoia nesta interface.

Palavras-chave Noção de pessoa, Ontologia, Fenomenologia indígena, Confiança, Intimidade, Socialidade, Povos amazônicos, Kaxinawá.

\section{Abstract}

The paper reexamines distinct approaches to the constitution of sociality in indigenous Amazonian contexts that differ with respect to the heuristic value attributed to "trust" and "intimacy", in the light of Huni Kuin (Cashinahua) ethnography of the body, personhood, trust and thought. For Huni Kuin people thinking and trusting are embodied processes that are constitutive of sociality among living persons. Grounded in a critical appreciation of the uses of the analytical frameworks emerging from discussions of "Amazonian perspectivism" and "fractality" for revealing the indigenous ontologies at work, the paper argues that it is necessary to go beyond an ontological emphasis and also take into consideration its interface with indigenous epistemology and phenomenology. It argues that Huni Kuin perspectivist understanding of the engagement of virtual sociality and lived sociality in a multinatural universe depends upon this interface.

Key words Personhood, Ontology, Indigenous phenomenology, Trust, Intimacy, Sociality, Amazonian peoples, Cashinahua. 